Article

\title{
Some Properties of Electron Beam-Irradiated Sheep Wool Linked to Cr(III) Sorption
}

\author{
Jana Braniša ${ }^{1}$, Angela Kleinová ${ }^{2}$, Klaudia Jomová ${ }^{1}$, Radka Malá ${ }^{1}$, Volodymyr Morgunov ${ }^{3}$ and \\ Mária Porubská 1 * (D) \\ 1 Constantine the Philosopher University in Nitra, Faculty of Natural Sciences, Department of Chemistry, \\ Tr. A. Hlinku 1, 94974 Nitra, Slovakia; jbranisa@ukf.sk (J.B.); kjomova@ukf.sk (K.J.); \\ radka.mala.11@gmail.com (R.M.) \\ 2 Polymer Institute, Slovak Academy of Sciences, Dúbravská cesta 9, 84541 Bratislava 45, Slovakia; \\ Angela.Kleinova@savba.sk \\ 3 PROGRESA FINAL SK, s.r.o., Ferienčíkova 18, 81108 Bratislava-Staré Mesto, Slovakia; \\ volodymyr.morgunov@progresafinal.sk \\ * Correspondence: mporubska@ukf.sk; Tel.: +421-37-6408-655
}

Received: 4 November 2019; Accepted: 19 November 2019; Published: 2 December 2019

\begin{abstract}
We examined the characteristics of an electron beam irradiated wool with an absorbed dose of (21-410) kGy in comparison with natural wool with respect to the determination of the isoelectric point (IEP), zero charge point (ZCP), mechanism of $\mathrm{Cr}$ (III) sorption from higher concentrated solutions, and the modelling of the wool-Cr(III) interaction. The data of ZPC and IEP differed between natural and irradiated samples. Increasing the dose shifted the $\mathrm{pH}$ of ZPC from 6.85 for natural wool to 6.20 for the highest dosed wool, while the natural wool IEP moved very little, from $\mathrm{pH}=3.35$ to 3.40 for all of the irradiated samples. The sorption experiments were performed in a $\mathrm{pH}$ bath set at 3.40 , and the determination of the residual $\mathrm{Cr}(\mathrm{III})$ in the bath was performed by VIS spectrometry under optimized conditions. The resulting sorptivity showed a monotonically rising trend with increasing $\mathrm{Cr}(\mathrm{III})$ concentration in the bath. Lower doses, unlike higher doses, showed better sorptivity than the natural wool. FTIR data indicated the formation of complex chromite salts of carboxylates and cysteinates. Crosslinks via ligands coming from different keratin chains were predicted, preferably on the surface of the fibers, but to a degree that did not yet inhibit the diffusion of $\mathrm{Cr}$ (III)-cations into the fiber volume. We also present a concept of a complex octahedral structure.
\end{abstract}

Keywords: sheep wool; electron irradiation; point of zero charge; isoelectric point; chromium sorption; chromium complex

\section{Introduction}

In technologies using chromium salts, adsorption can be exploited to pre-concentrate small chromium quantities for various purposes as well as in waste water management.

Considering the application of inorganic adsorption materials for chromium, Bedemo et al. [1] described the removal of $\mathrm{Cr}$ (III) from aqueous solution using aluminum oxide hydroxide. Park et al. [2] examined the feasibility of hexavalent chromium removal using mackinawite (FeS)-coated sand, which completely reduced $\mathrm{Cr}(\mathrm{VI})$ to $\mathrm{Cr}(\mathrm{III})$. Dong et al. [3] made poly(catechol-1,4-butanediamine)-coated $\mathrm{Fe}_{3} \mathrm{O}_{4}$ composite capable of successfully removing $\mathrm{Cr}(\mathrm{VI})$, some part of which could be reduced partially to $\mathrm{Cr}$ (III). Defective porous boron nitride was successfully tested for adsorption of $\mathrm{Cr}(\mathrm{III}) / \mathrm{Cr}(\mathrm{VI})$ [4], and the results clarified that the strong adsorption of both ions is chemisorption, and not dispersion or electrostatic attraction. Zhu et al. [5] prepared nanoscale zero-valent iron/nickel and tested $\mathrm{Cr}(\mathrm{VI})$ removal along with the influence of co-existing anions $\left(\mathrm{CO}_{3}{ }^{2-}, \mathrm{HCO}_{3}{ }^{-}, \mathrm{SO}_{4}{ }^{2-}\right.$ and $\left.\mathrm{NO}_{3}{ }^{-}\right)$. The anions inhibited $\mathrm{Cr}(\mathrm{VI})$ removal, and $\mathrm{CO}_{3}{ }^{2-}$ had the most adverse effect. 
Organic adsorbents for chromium involve synthetic or natural materials after modification. Carbonized wheat and barley straw oxidized by nitric acid showed a high adsorption towards Cr(III) [6]. Lyubchik et al. [7] prepared activated carbons for $\mathrm{Cr}$ (III) from co-mingled natural organic wastes. As presented by Su et al. [8], activated carbon modified with micro-sized goethite adsorbed $\mathrm{Cr}(\mathrm{VI})$ well, reducing it to $\mathrm{Cr}$ (III). Composite polyethylenimine-silica nanoparticles removed chromium from solution being $\mathrm{Cr}(\mathrm{VI})$, which was reduced partially to $\mathrm{Cr}$ (III) by amine group, whereby $\mathrm{Cr}$ (III) and $\mathrm{Cr}(\mathrm{VI})$ ions were adsorbed on different functional groups [9]. Mortazavian et al. [10] applied nano-scale zero-valent iron particles onto active carbon for simultaneous adsorption and reduction of $\mathrm{Cr}(\mathrm{VI})$ from aquatic solutions. Magnetic corncob biochar/polypyrrole composite applied for $\mathrm{Cr}(\mathrm{VI})$ adsorption showed combination of adsorption and reduction [11]. The presented mechanism involved (a) adsorption of $\mathrm{Cr}(\mathrm{VI})$ anions onto the surface followed by a partial anion exchange with $\mathrm{Cl}$, (b) reduction of the adsorbed anions to $\mathrm{Cr}$ (III) by amine and hydroxyl groups, and (c) immobilization of generated $\mathrm{Cr}$ (III) via precipitation and chelation. Examining the biosorption potential of raw and chemically modified Vetiveria zizanioides grass for chromium (VI) removal, Tyagi and Khandegar [12] found that acid-modified bioadsorbents exhibited the highest efficiency. Also, Surendran and Baral [13] reported similar results for grass Sorghastrum Nutans L. Nash, pointing out that $\mathrm{pH}$ plays the most important role in $\mathrm{Cr}(\mathrm{VI})$ adsorption. Furthermore, application of several composite adsorbents for chromium is the topic of many published papers [14-17], and this could be the subject of a large review work.

As far as biosorbents of animal origin, they are practically limited to sheep wool [18-20]. Today, with wool being forced from the market by synthetic fibers, it is becoming an unavoidable and unwanted waste, bearing additional costs in the form of its disposal as hazardous waste. That is why some chemical modifying methods for wool have been investigated. Recent works have also presented a new radiative procedure of the modification using irradiation of sheep wool by accelerated electron beam [21,22]. Such treatment improves sorption affinity towards some metal cations [23-26]. However, much information is still unknown. The adsorption property of sheep wool is one of its many characteristics. In general, all authors dealing with adsorption processes, applied low adsorbate concentrations and obtained some standard adsorption isotherms. Since we found interesting anomalies using higher $\mathrm{Cu}$ (II) or $\mathrm{Co}$ (II) concentrations $[25,26]$ under the sorption on the irradiated wool, this study is focused on further data gathering connected with $\mathrm{Cr}(\mathrm{III})$ sorption on natural and electron irradiated sheep wool when $\mathrm{Cr}$ (III) concentration was higher, too. Investigation in this field is worthwhile, because sheep wool is a renewable and cheap resource that is usable for environmental cleaning as well as valuable material recycling.

\section{Results and Discussion}

\subsection{Impact of Absorbed Dose on Surface Properties of Wool (IEP/PZC)}

Both of the parameters isoelectric point (IEP) and point of zero charge (PZC) are coessential. While the corresponding $\mathrm{pH}$ values are the same in metallic oxides, this is not valid for materials with other characteristics [27]. Sheep wool is also such a material, being based on keratin. Here, it is a question of the sum of the charges of the dissociated amino acid side chains on the surface of the wool fibers potentially entering electrostatic interactions $\left(\mathrm{R}-\mathrm{COO}^{-+} \mathrm{H}_{3} \mathrm{~N}-\mathrm{R}\right)$.

The varied representation of amino acids with different side chain type in keratin does not allow the determination of the IEP of sheep wool by direct calculation from $\mathrm{pK}_{\mathrm{a}}$ data. Therefore, the IEP was estimated at $0.05 \mathrm{M} \mathrm{KCl}$, similar to other biosorbents of plant origin [28], where the effect of all components is involved. In addition, we tried to find the effect of wool irradiation on the PZC and IEP position, which is identified by the electrokinetic potential $\xi$ [29]. The data obtained are displayed in Figure 1. The wool PZCs corresponding to $\Delta \mathrm{pH}=0$ were read from the measured values. 


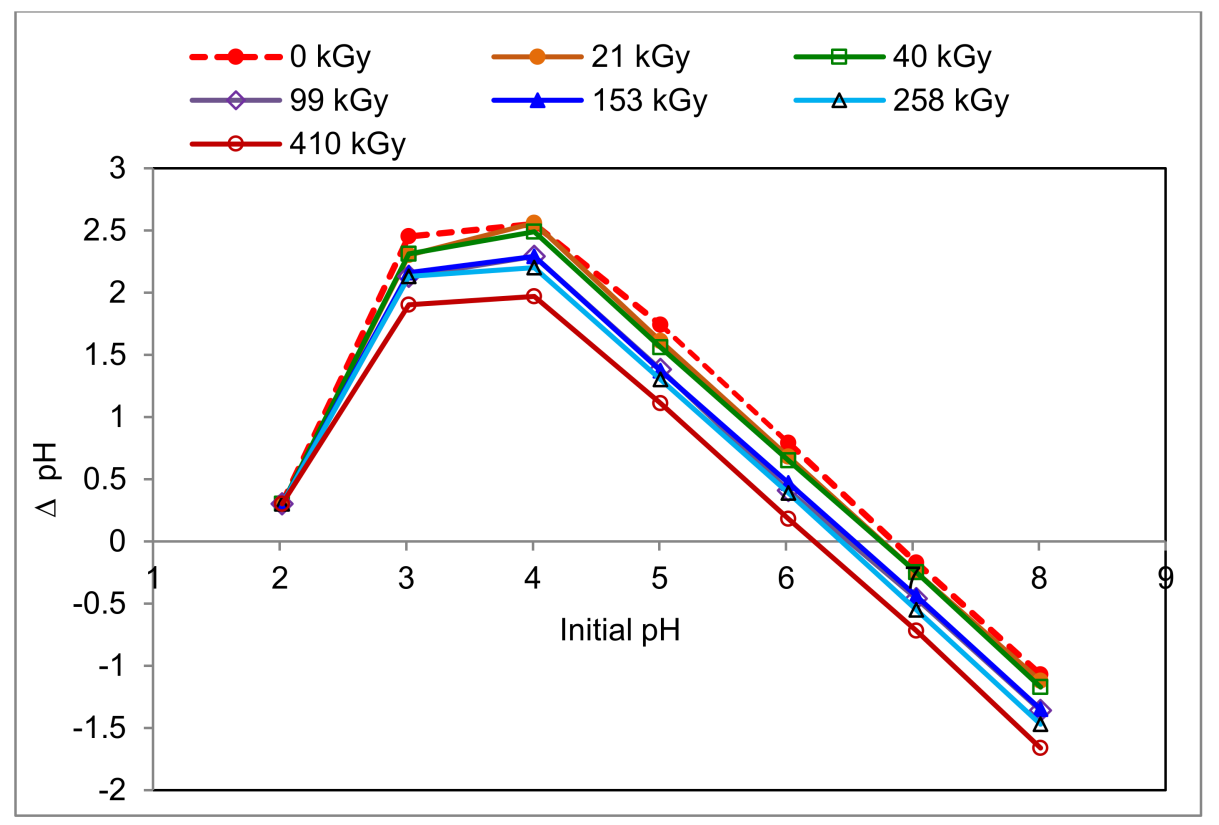

Figure 1. Variations of $\mathrm{pH}$ values in solution of $0.05 \mathrm{M} \mathrm{KCl}$ in contact with the sheep wool samples with one-year lapse from the exposure.

From the dependencies presented, it can be seen that the higher the dose is that has been absorbed by the wool, the lower $\mathrm{pH}$ will be for the PZC. The range of $\mathrm{pH}$ changes was from 6.85 for the non-irradiated wool to 6.2 for the $410 \mathrm{kGy}$ dose. This observation is related to earlier findings that the electron irradiation of wool increases the content of acidic groups due to the cysteine acid produced by the oxidation of the cleaved sulphur bridges [21,22]. On the other hand, if the content of acidic groups (carboxylic and cysteic acids) were the only factor influencing the $\mathrm{Cr}$ (III) sorption of the wool, the sorption should theoretically increase with the absorbed dose. This assumption is not valid over the full range of applied concentrations (see below), which indicates that the substitution mechanism of chromium salt formation from acid residues is not the only one in the modified wool.

The $\mathrm{pH}$ belonging to peak on the $x$-axis corresponds to IEP. A rough reading from the graph (Figure 1) gives a uniform $\mathrm{pH}=4.0$ for IEP. In general, this value with some variations (3.3-4.5) is also reported by other authors [29-31]. According to Capablanca et al. [29], this figure varies with time and manner of wool scouring. When we approximated the IEP position from the intersection of the elongated side branches of the curves, slightly lower and slightly differentiated values were obtained (Table 1).

Table 1. Position of isoelectric point (IEP) for sheep wool with one-year lapse from electron beam irradiation. The IEP is estimated by approximation from Figure 1.

\begin{tabular}{cccccccc}
\hline Dose absorbed by wool (kGy) & 0 & 21 & 40 & 99 & 153 & 258 & 410 \\
\hline IEP as $\mathbf{p H}_{\max }$ estimated from Figure 1 & 3.35 & 3.40 & 3.40 & 3.40 & 3.40 & 3.40 & 3.40 \\
\hline
\end{tabular}

This finer reading shows a lower $\mathrm{pH}$ (3.35) for the non-irradiated wool than for all irradiated samples (3.40). This difference is very small, almost bordering on experimental error. However, regarding the equipment accuracy declared by the manufacturer $( \pm 0.002 \mathrm{pH})$ and relative deviation of the measured values $(0.5 \%$ max. $)$, the covering intervals of those average figures $(<3.335-3.367>$; $<3.383-3.417>$ ) do not yet overlap, so the difference should be accepted. In such cases, the difference should correspond to the consumed proton concentration by $4.86 \cdot 10^{-2} \mathrm{mmol} \cdot \mathrm{dm}^{-3}$. We can speculate about two possible reasons. The first is the structural disruption after the wool irradiation and related destruction of the electrostatic interactions due to conformational variations. To complete $\mathrm{R}^{-\mathrm{COO}^{-}}$to 
R-COOH, the carboxyl ions bind to the $\mathrm{H}^{+}$from $\mathrm{H}_{2} \mathrm{O}$, decreasing the $\mathrm{H}^{+}$concentration in the solution and increasing the $\mathrm{OH}^{-}$concentration:

$$
\mathrm{R}-\mathrm{COO}^{-}+\mathrm{HOH} \rightarrow \mathrm{R}-\mathrm{COOH}+\mathrm{OH}^{-}
$$

The second reason could be due to the S-S bond being split by the electron beam, followed by oxidation of the created S-radicals with the following transformation of $\mathrm{R}-\mathrm{S}-\mathrm{SO}_{3}{ }^{-}, \mathrm{R}-\mathrm{S}-\mathrm{SO}^{-}, \mathrm{R}^{-S}-\mathrm{SO}_{2}{ }^{-}$ to $\mathrm{R}_{-} \mathrm{SO}_{3}{ }^{-}$. The latter binds to the $\mathrm{H}^{+}$provided by $\mathrm{H}_{2} \mathrm{O}$, giving $\mathrm{R}-\mathrm{SO}_{3} \mathrm{H}$ :

$$
\mathrm{R}_{-} \mathrm{SO}_{3}{ }^{-}+\mathrm{HOH} \rightarrow \mathrm{R}-\mathrm{SO}_{3} \mathrm{H}+\mathrm{OH}^{-}
$$

The hydroxyl groups resulting from both processes increase the $\mathrm{pH}$ value accordingly. The growth is the same for every dose, since representation of the S-oxidized products on the surface is similar. Concerning the time lapse effect [26], for other, especially shorter time periods, these values may change due to the transformation dynamics of S-oxidized species. However, in principle, the PZC and IEP will not be identical for the irradiated and non-irradiated samples.

\subsection{Effect of $p H$ on VIS Spektra of $\mathrm{Cr}$ (III)}

Changing the $\mathrm{pH}$ of the $\mathrm{KCl}$ solution with the dose (Figure 1) indicates that the resulting $\mathrm{pH}$ of the sorption bath will change with the absorbed dose. This may affect the VIS-spectral evaluation of residual $\mathrm{Cr}(\mathrm{III})$ content in the bath. Therefore, we verified whether and how the VIS spectrum of $50 \mathrm{mM} \mathrm{KCr}\left(\mathrm{SO}_{4}\right)_{2}$ solution changes with $\mathrm{pH}$ change (Figure 2) in the range of (3.0-4.6) $\mathrm{pH}$ units. To minimize dilution of the measured solutions, $10 \mathrm{M} \mathrm{NaOH}$ or $\mathrm{HCl}$ solutions were used to adjust the desired $\mathrm{pH}$. After adjusting the $\mathrm{pH}$ to 4.8, precipitation of hydrated $\mathrm{Cr}_{2} \mathrm{O}_{3}$ was already observed. From Figure 2, it is evident that increasing the $\mathrm{pH}$ increases the absorbance and shifts $\lambda_{\max }$ of both absorption bands to a higher $\lambda$. The first band in the solution with $\mathrm{pH}=3\left(\lambda_{\max }=409 \mathrm{~nm}\right)$ corresponds to the absorbance $\mathrm{A}=0.8877$, while for $\mathrm{pH}=4.6\left(\lambda_{\max }=422 \mathrm{~nm}\right)$ the absorbance was measured to 1.2998. Thus, for the mentioned $\mathrm{pH}$ range, $\Delta \lambda_{\max 1}=13 \mathrm{~nm}$ and the increase in absorbance $\Delta \mathrm{A}_{1}=0.41$. For the second band for $\mathrm{pH}=3\left(\lambda_{\max }=577 \mathrm{~nm}\right)$ the absorbance of 0.7648 is observed and 0.9916 for $\mathrm{pH}=4.6\left(\lambda_{\max }=582 \mathrm{~nm}\right)$, corresponding to $\Delta \lambda_{\max 2}=5 \mathrm{~nm}$ and $\Delta \mathrm{A}_{2}=0.227$.

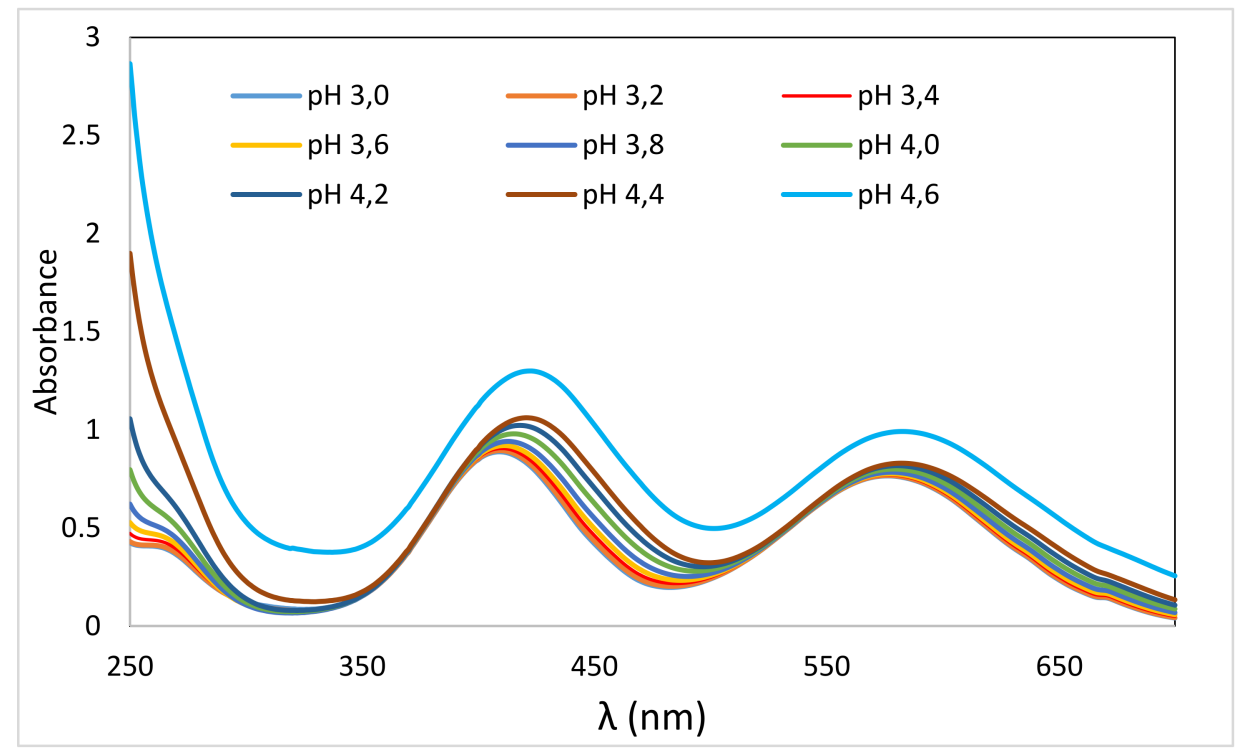

Figure 2. VIS spectra taken from solutions of $\mathrm{KCr}\left(\mathrm{SO}_{4}\right)_{2}\left(\mathrm{c}=50 \mathrm{~mol} . \mathrm{dm}^{-3}\right)$ with different $\mathrm{pH}$ values.

The increase in $\lambda_{\max }$ and the absorbance with increasing $\mathrm{pH}$ was also observed in $50 \mathrm{mM}$ $\mathrm{Cr}\left(\mathrm{NO}_{3}\right)_{3} .9 \mathrm{H}_{2} \mathrm{O}$ solution by Hamada et al. [32] when varying the $\mathrm{pH}$ from 2.82 to 5.05 . The spectral 
changes are related to hydrolytic processes, to which $\mathrm{Cr}$ (III) has a strong tendency. The hydrolysis products are polynuclear complexes with $\mathrm{OH}$-bridges. The hydroxy groups required for this are formed from coordinated water molecules by proton loss, followed by coordination of $\mathrm{OH}^{-}$groups [33]. The hydrolytic process was studied by Drljaca and Spiccia [34] and Hiroishi et al. [35], who observed a supportive effect of increasing $\mathrm{pH}$. Indeed, the observed spectral changes are the result of hydrolytic processes in our case as well.

Since the measurement of the Cr(III) sorption by the wool involves scanning the VIS spectra of the residual chromium in the bath, it was also necessary to take into account the $\mathrm{pH}$ effect demonstrated above (Figure 2) on the respective calibration curve in order to reflect the real final situation in the measured bath. The change in the initial $\mathrm{pH}$ of the bath based on the absorbed dose by wool was tested on $50 \mathrm{mM} \mathrm{KCr}\left(\mathrm{SO}_{4}\right)_{2} \cdot 12 \mathrm{H}_{2} \mathrm{O}$ solutions after $24 \mathrm{~h}$ contact with each wool sample. We found that the initial $\mathrm{pH}=3.14$ for doses of (0-410) $\mathrm{kGy}$ varied only within a narrow range of $3.34 \pm 0.02$. Therefore, we set the $\mathrm{pH}$ of the calibration solutions to 3.34. In addition, in order to eliminate any potential interfering effects of other bath components on the spectral drift, we used an aqueous extract from the non-irradiated wool prepared in a manner consistent with the samples to prepare the calibration solutions. The calculated amounts of $\mathrm{KCr}\left(\mathrm{SO}_{4}\right)_{2} \cdot 12 \mathrm{H}_{2} \mathrm{O}$ were dissolved in the filtered aqueous extract and the $\mathrm{pH}$ of the calibration solutions adjusted to 3.34 to match $\mathrm{pH}$ of the sorption bath. The band with $\lambda=583 \mathrm{~nm}$ was used for analysis, which appeared more stable and, in contrast to the band at $\lambda=415 \mathrm{~nm}$, allowed a more accurate measurement of the higher concentration. Under these conditions, the calibration curve showed $\mathrm{R}^{2}=1.0000$.

\subsection{Sorptivity}

The sorption experiments were performed with the wool of 120 days after the exposure, when the wool structure was considered sufficiently stabilized [22]. Using VIS spectral data for the band $\lambda_{\max }=$ $583 \mathrm{~nm}$, the corresponding biosorptive dependencies were calculated (Figure 3).

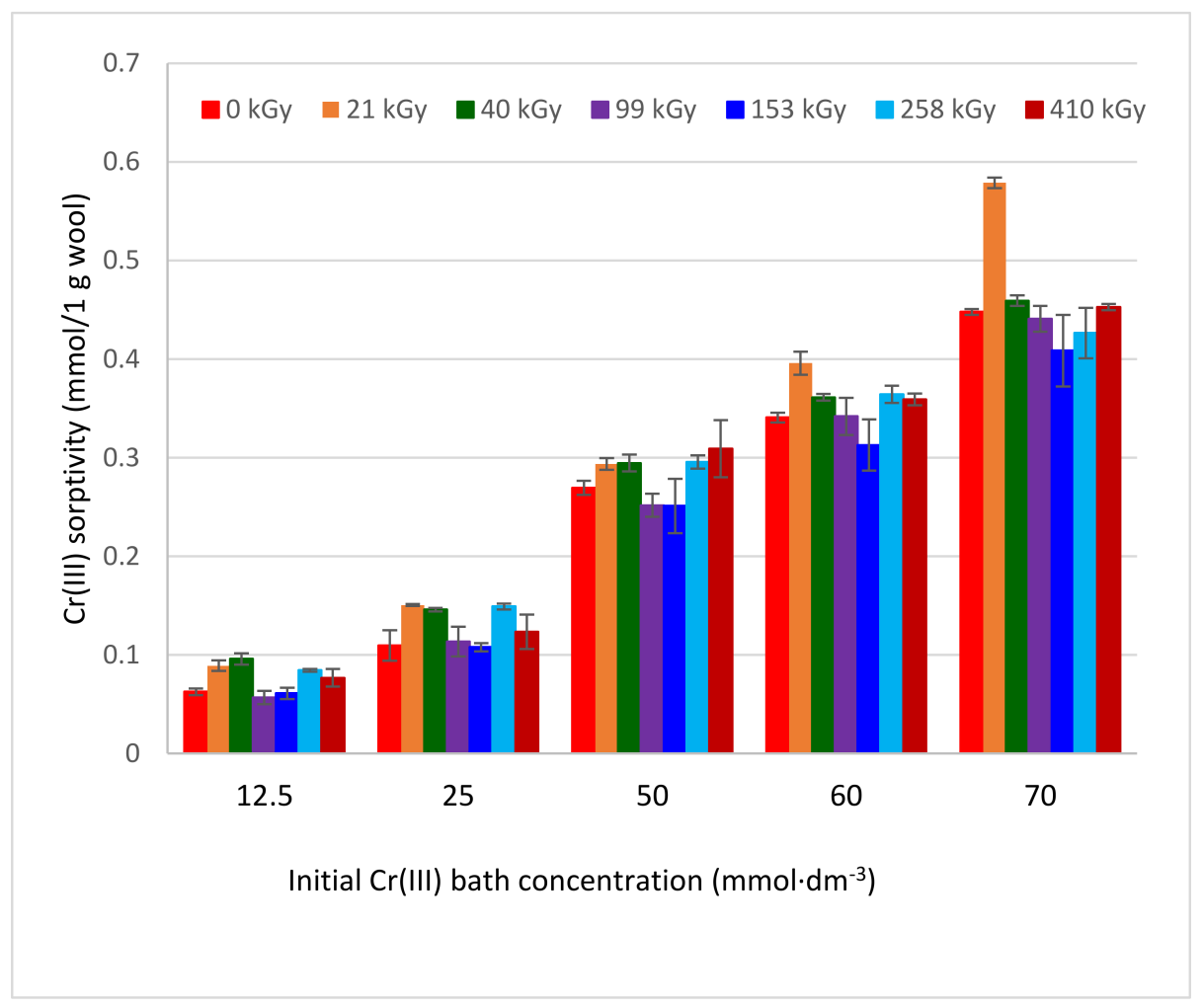

Figure 3. Variations of $\mathrm{Cr}(\mathrm{III})$ sorptivity onto irradiated sheep wool depending on concentration and absorbed dose. 
All obtained dependencies were monotonically growing, without extremes, and mostly tended towards convex. They were dissimilar to the expected standard relations because the sorbent and sorbate concentrations were atypical, as was shown for $\mathrm{Cu}$ (II) [25] and $\mathrm{Co}$ (II) [26]. This may be due to the specific effect of EB modifying the fiber bulk, not just its surface. On the other hand, complexation capacity of the cations is different, too. Here, within the range of standard deviations, some of the dependencies overlap, but others are different, such as $21 \mathrm{kGy}$, especially. It can be seen that the smallest deviations are at lower concentrations. The observed differences can be attributed to sample inhomogeneity only to a small extent since the wool was taken from the identical site. While any noticeable correlation is not apparent between the irradiation dose and the $\mathrm{Cr}$ (III) amount sorbed within the mentioned concentration range, low concentrations of $\mathrm{Cr}(\mathrm{III})$, as well as other cations $[23,24]$ showed a visible positive effect of the absorbed dose on the sorption. We assume the main reason for this is that the $\mathrm{Cr}$ (III) concentration is already high enough to create a complex salt(s) on the fiber surface affecting diffusion of the next ions into the bulk and overlapping the difference between the samples.

For simplified modelling of the interaction of $\mathrm{Cu}(\mathrm{II})$ and $\mathrm{Co}(\mathrm{II})$ with irradiated wool, the reaction with arginine was used [25,26], since arginine is one of the most abundant amino acids in keratin [36]. In both cases, the formation of soluble complex salts has been spectrally demonstrated. We used this model for $\mathrm{Cr}(\mathrm{III})$, too. However, the product of the reaction of $\mathrm{KCr}\left(\mathrm{SO}_{4}\right)_{2} \cdot 12 \mathrm{H}_{2} \mathrm{O}$ with arginine was a relatively fast-forming greenish precipitate with a color shade similar to the wool after contact with the chromium bath.

Arginine (2-amino-5-guanidinopentanoic acid $\mathrm{C}_{6} \mathrm{H}_{14} \mathrm{~N}_{4} \mathrm{O}_{2}$ ) is an amino acid with a basic guanidine ending and thus, in an aqueous medium, the hydrogen at the ending amino group is not acidic. The nature of the acid-base reaction of arginine is a function of the medium $\mathrm{pH}$. In acidic medium at $\mathrm{pH}<$ IEP the carboxyl group - $\mathrm{COOH}$ is not dissociated and positive charges on the amino and imino groups $\left(-\mathrm{NH}_{3}{ }^{+}\right)$are. As a result of competition with $\mathrm{H}^{+}$from the acid medium, the positive charges on the arginine ending group will repel the positively charged $\mathrm{Cr}^{3+}$. Above IEP at $\mathrm{pH}>\mathrm{IEP}$, the carboxyl group starts to dissociate, and as the $\mathrm{pH}$ increases, the dissociation deepens. Under these conditions, arginine may form a chromium salt. Since the arginine solution exhibits $\mathrm{pH} \approx 8$, the precipitate formed should correspond to chromium arginate. Moreover, since the $\mathrm{Cr}(\mathrm{III})$ atom forms complexes with all Lewis bases in practice, the precipitate represents a complex chromite salt, a chelate. All chromium complexes without exception have a coordination number of 6 and an octahedral form [37]. In the arginine-Cr(III) complex considered, regarding a planar arrangement of the guanidine moiety, it can be expected that two arginine molecules will fulfill the role of four ligands (each arginine molecule is a bidentate ligand) and two other molecules, probably water (or $\mathrm{SO}_{4}{ }^{2-}$ ), complete the number of ligands to six by monodentate occupations of the 2 remaining coordination sites. Such a state could correspond to the structural concept in Figure 4, where X may be a sulphate or hydroxyl anion, in the case of wool also a carboxyl or cysteinate anion:

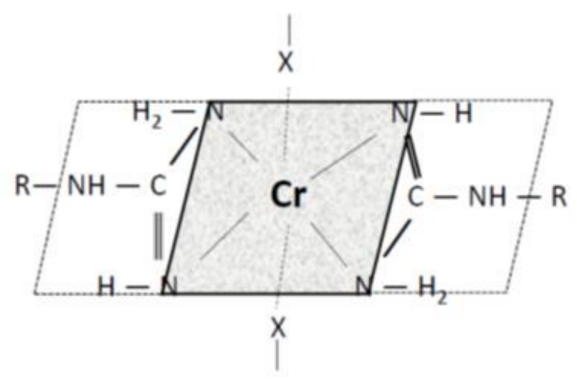

Figure 4. Concept of the $\mathrm{Cr}(\mathrm{III})$-arginine complex.

The formation of the precipitate in reaction of $\mathrm{KCr}\left(\mathrm{SO}_{4}\right)_{2}$ with arginine in the aqueous solution is only a considerable simplification of the model situation in sheep wool. There are, in addition 
to arginine side chains, many others that can limit or modify an analogous reaction. Moreover, the presence of at least two arginine guanidine moieties at a suitable position to $\mathrm{Cr}$ (III) is necessary to precipitate the complex. Unlike the arginine solution, such a situation is likely to occur rarely in wool; therefore, other mechanisms also participate in the binding of $\mathrm{Cr}$ (III) to the fiber. If only one guanidine moiety is available as the ligand, another ligand may be provided by an amine or hydroxy group of another side chain coming from a different keratin molecule. Therefore, as with Cu (II) [25], the crosslinking of the chains must also occur in the case of $\mathrm{Cr}(\mathrm{III})$. Depending on the nature of the participating part of the keratin chain, the resulting octahedron may be the same as in the model reaction, or degenerated. The question is why at higher cation concentrations two extremes were observed on sorption isotherms for $\mathrm{Cu}$ (II) with comparable concentrations, unlike $\mathrm{Cr}$ (III), although both cations tend to form complexes. In particular, $\mathrm{pH}$ medium impact can be considered. The $\mathrm{KCr}\left(\mathrm{SO}_{4}\right)_{2}$ sorption bath has $\mathrm{pH}$ of $\approx 3.3$, which corresponds to the IEP vicinity, while the corresponding bath $\mathrm{pH}$ for $\mathrm{Cu}$ (II) $(\mathrm{pH} \approx 4)$ was higher than the IEP. In the vicinity of IEP, the dissociation of -COOH is only beginning, and deepens with increasing $\mathrm{pH}$. This indicates that the situation for formation of the $\mathrm{Cr}$ (III) salt via substitution reaction is less favorable than that of $\mathrm{Cu}(\mathrm{II})$. Since the formation of the $\mathrm{Cr}$ (III) salt (carboxylate, cysteinate) is a precursor of the complex creation, fewer complex forms hindering access of further cations into the fibers will be formed in the lower $\mathrm{pH}$ environment. Therefore, a decrease in $\mathrm{Cr}$ (III) sorption is not observed in the applied concentration range. Comparing the sorption capacity of $\mathrm{Cu}$ (II) [25] with $\mathrm{Cr}$ (III) for a similar concentration interval and sorption recalculated to millimoles/g, we can see that the range of the corresponding capacity $(0.11-0.236) \mathrm{mmol} / \mathrm{g}$ for $\mathrm{Cu}(\mathrm{II})$ is narrower than (0.054-0.48) $\mathrm{mmol} / \mathrm{g}$ for $\mathrm{Cr}(\mathrm{III})$. This comparison supports our previous finding that the complexing ability of $\mathrm{Cu}$ in wool is higher than that of $\mathrm{Cr}$ and hampers the diffusion of ions inside the fibers causing sorption extremes.

\subsection{FTIR Spectra Measurements}

The surface and internal wool structures are not the same. As already mentioned, the electron beam penetrates the entire wool bulk, modifying the surface as well as the internal structures. So infrared spectra can be an important contribution to qualitative understanding of the mechanism of $\mathrm{Cr}$ (III) sorption into both natural and irradiated wool. Comparison of the transmission spectra taken from the whole wool volume and from the surface, ATR spectra, before (Figures 5 and 6) and after contact with the chromium bath (Figure 7and Figure 8) makes it possible to assess the running processes and possible differences. For better survey, in addition to the more detail spectra within the $900-1300 \mathrm{~cm}^{-1}$ region (Figures 5 and 7), also entire the middle IR region is shown (Figures 6 and 8).

Spectral analysis revealed several differences. The band around $1048 \mathrm{~cm}^{-1}$ pertaining to cysteine acid [21,38] in both volume and sample surface is more pronounced before contact with $\mathrm{Cr}$ (III) (Figure 5) than after the contact (Figure 7), indicating acid consumption in reaction with the sorbate. More consistent structure of cystine monoxide bands at $1075 \mathrm{~cm}^{-1}$ [21] in the contacted samples (Figure 7 compared to finer structured bands of the contactless samples (Figure 5) is related to interaction of the monoxide with $\mathrm{Cr}(\mathrm{III})$. The $1090 \mathrm{~cm}^{-1}$ band in the non-contacted samples (Figure 5) is absent, but is noticeable in the volume of contacted samples, at most in $0 \mathrm{kGy}$ sample (Figure 7a). This corresponds to sulphate anion [38,39] sorbed from the $\mathrm{KCr}\left(\mathrm{SO}_{4}\right)_{2}$ bath, which we verified, as documented in Figure 9, which displays the $\mathrm{KCr}\left(\mathrm{SO}_{4}\right)_{2}$ spectrum deconvolution. 


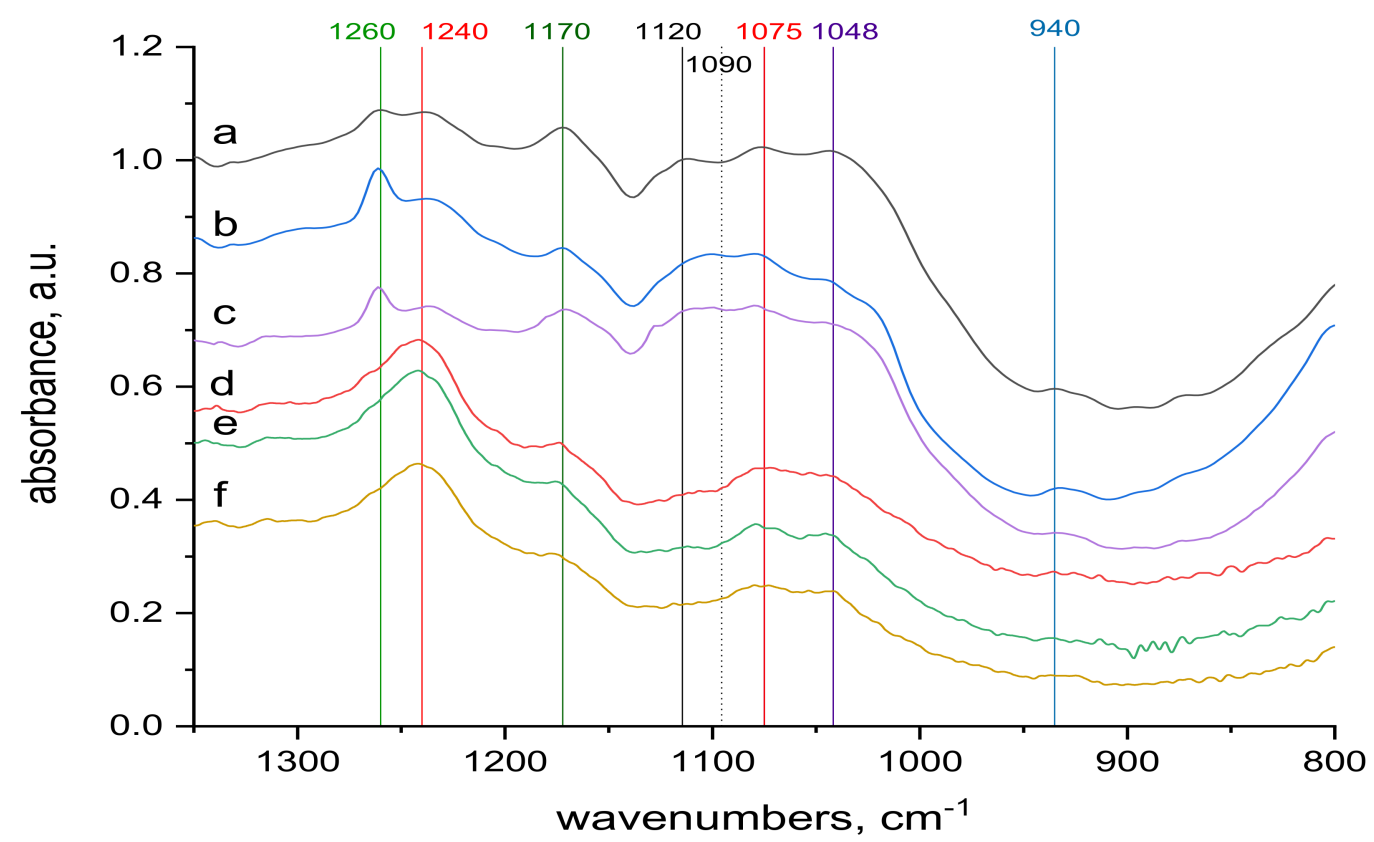

Figure 5. Spectra of reference materials (without $\mathrm{KCr}\left(\mathrm{SO}_{4}\right)_{2} \cdot 12 \mathrm{H}_{2} \mathrm{O}$ treatment), region $\left(900-1300 \mathrm{~cm}^{-1}\right.$ ); from up to down: (a) transmission spectrum of wool with $0 \mathrm{kGy}$ dose; (b) transmission spectrum of wool with $21 \mathrm{kGy}$ dose; (c) transmission spectrum of wool with $153 \mathrm{kGy}$ dose; (d) ATR spectrum of wool with 0 kGy dose; (e) ATR spectrum of wool with $21 \mathrm{kGy}$ dose; (f) ATR spectrum of wool with 153 kGy dose.

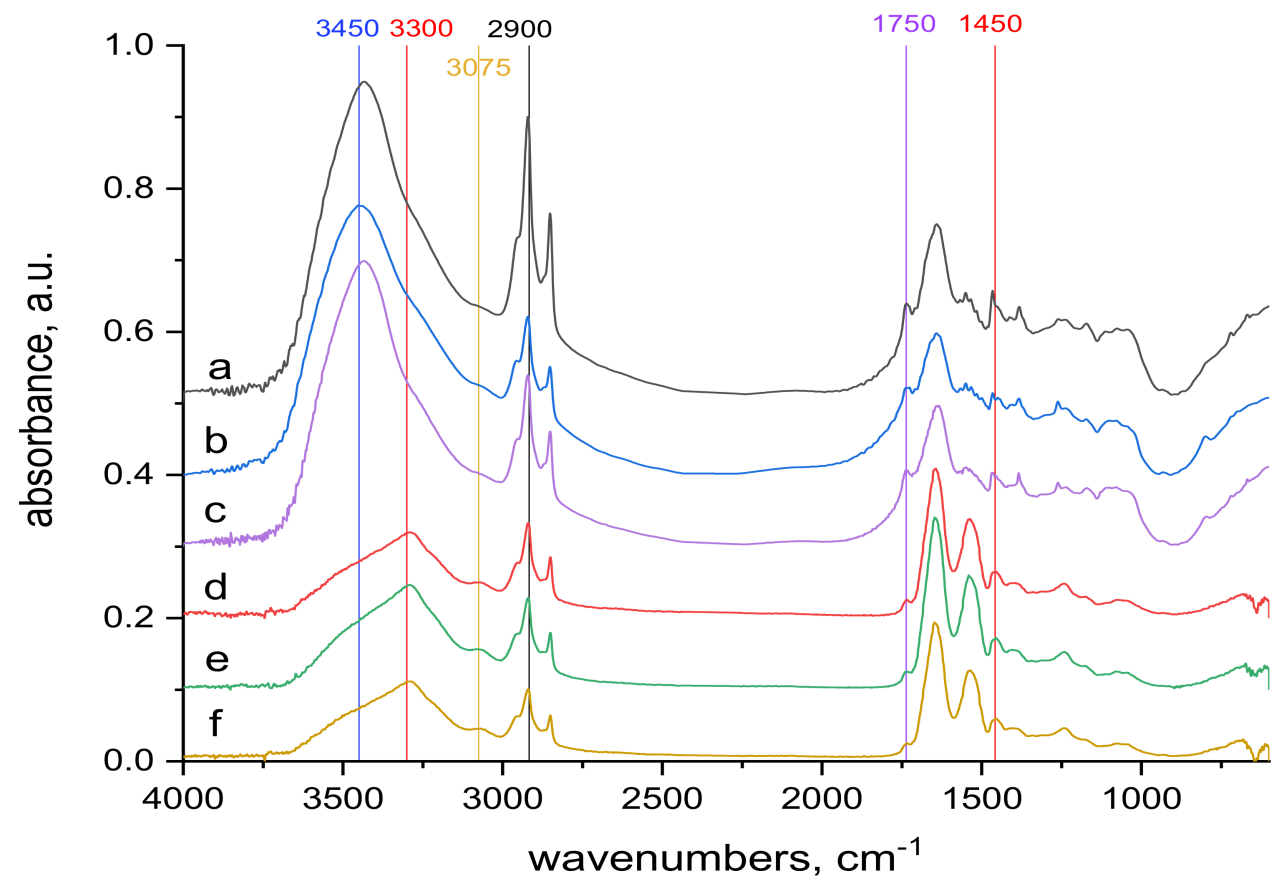

Figure 6. Spectra of reference materials (without $\mathrm{KCr}\left(\mathrm{SO}_{4}\right)_{2} \cdot 12 \mathrm{H}_{2} \mathrm{O}$ treatment), the whole mid-infrared region (400-4000) $\mathrm{cm}^{-1}$; from up to down: (a) transmission spectrum of wool with $0 \mathrm{kGy}$ dose; (b) transmission spectrum of wool with $21 \mathrm{kGy}$ dose; (c) transmission spectrum of wool with $153 \mathrm{kGy}$ dose; (d) ATR spectrum of wool with 0 kGy dose; (e) ATR spectrum of wool with $21 \mathrm{kGy}$ dose; (f) ATR spectrum of wool with $153 \mathrm{kGy}$ dose. 


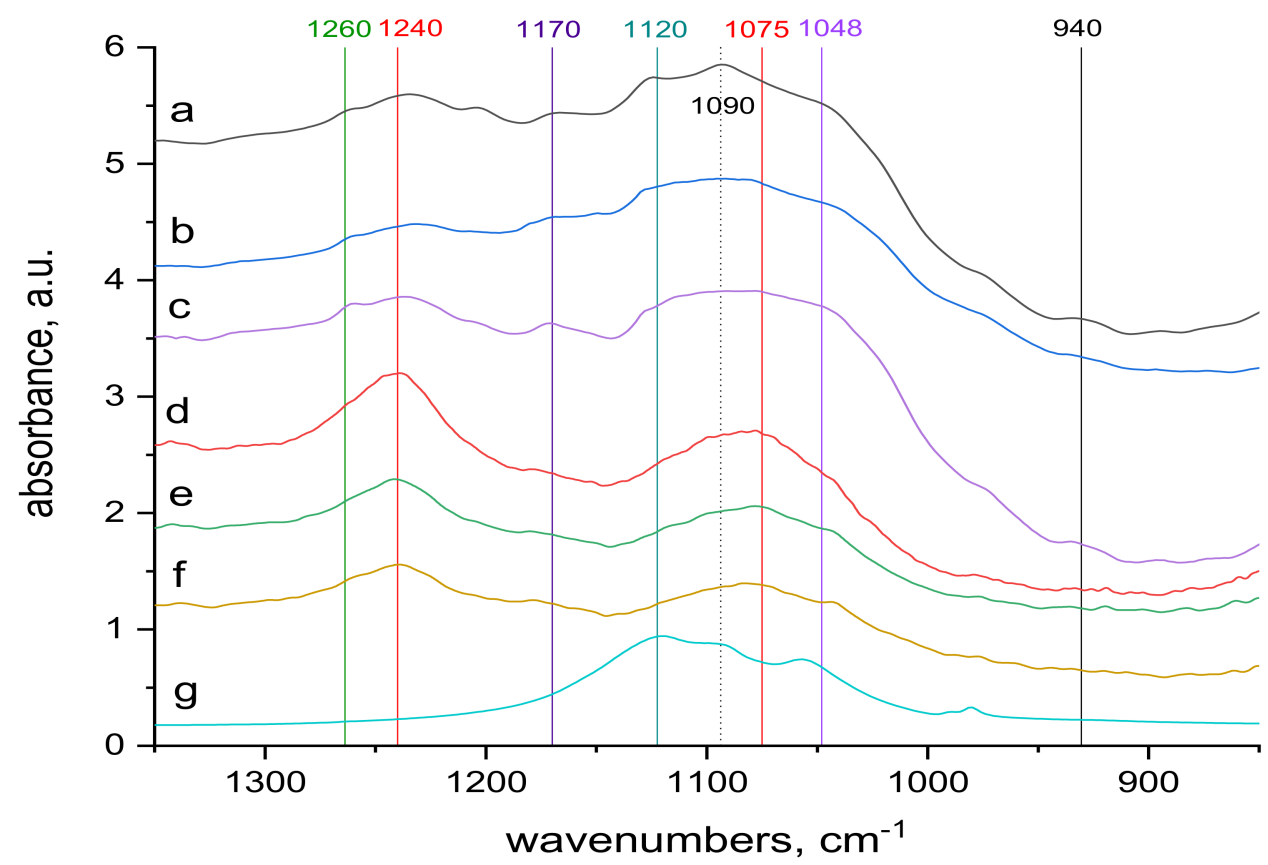

Figure 7. Comparison of the transmission and ATR spectra of wool with absorbed doses $0 \mathrm{kGy}, 21 \mathrm{kGy}$ and $153 \mathrm{kGy}$, respectively, after contact with $70 \mathrm{mM} \mathrm{KCr}\left(\mathrm{SO}_{4}\right)_{2} .12 \mathrm{H}_{2} \mathrm{O}$ solution, region $(900-1300) \mathrm{cm}^{-1}$; from top to bottom: (a-c) transmission spectra of $0 \mathrm{kGy}, 21 \mathrm{kGy}$ and $153 \mathrm{kGy}$ dosed samples; (d-f) ATR spectra of 0 kGy, $21 \mathrm{kGy}$ and $153 \mathrm{kGy}$ dosed samples; (g) spectrum of $\mathrm{KCr}\left(\mathrm{SO}_{4}\right)_{2} \cdot 12 \mathrm{H}_{2} \mathrm{O}$.

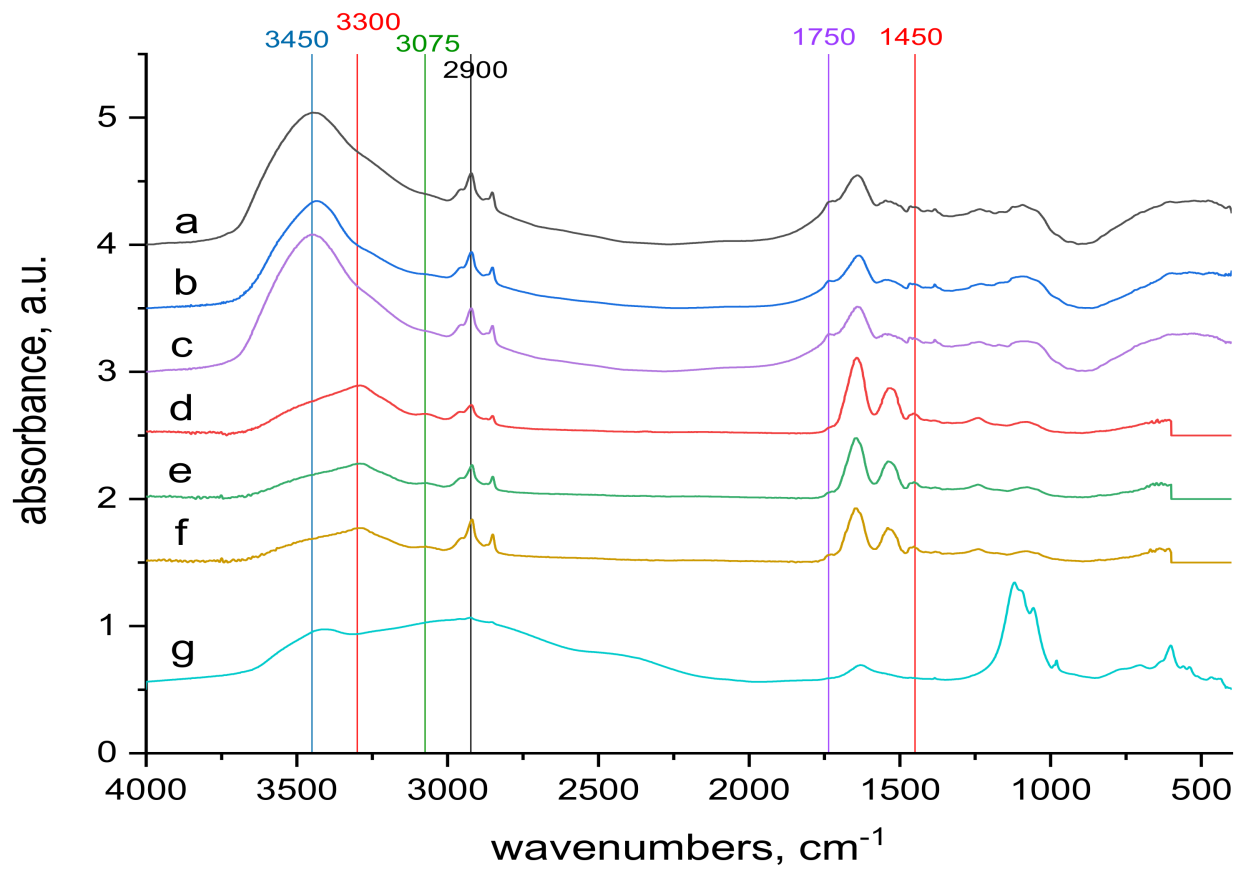

Figure 8. Comparison of the transmission and ATR spectra of wool with absorbed doses $0 \mathrm{kGy}, 21 \mathrm{kGy}$ and $153 \mathrm{kGy}$ respectively after contact with $70 \mathrm{mM} \mathrm{KCr}\left(\mathrm{SO}_{4}\right)_{2} \cdot 12 \mathrm{H}_{2} \mathrm{O}$ solution; the whole mid-infrared region (400-4000) $\mathrm{cm}^{-1}$; from top to bottom: (a-c) transmission spectra of $0 \mathrm{kGy}, 21 \mathrm{kGy}$ and $153 \mathrm{kGy}$ dosed samples; (d-f) ATR spectra of $0 \mathrm{kGy}, 21 \mathrm{kGy}$ and $153 \mathrm{kGy}$ dosed samples, (g) spectrum of $\mathrm{KCr}\left(\mathrm{SO}_{4}\right)_{2} \cdot 12 \mathrm{H}_{2} \mathrm{O}$. 


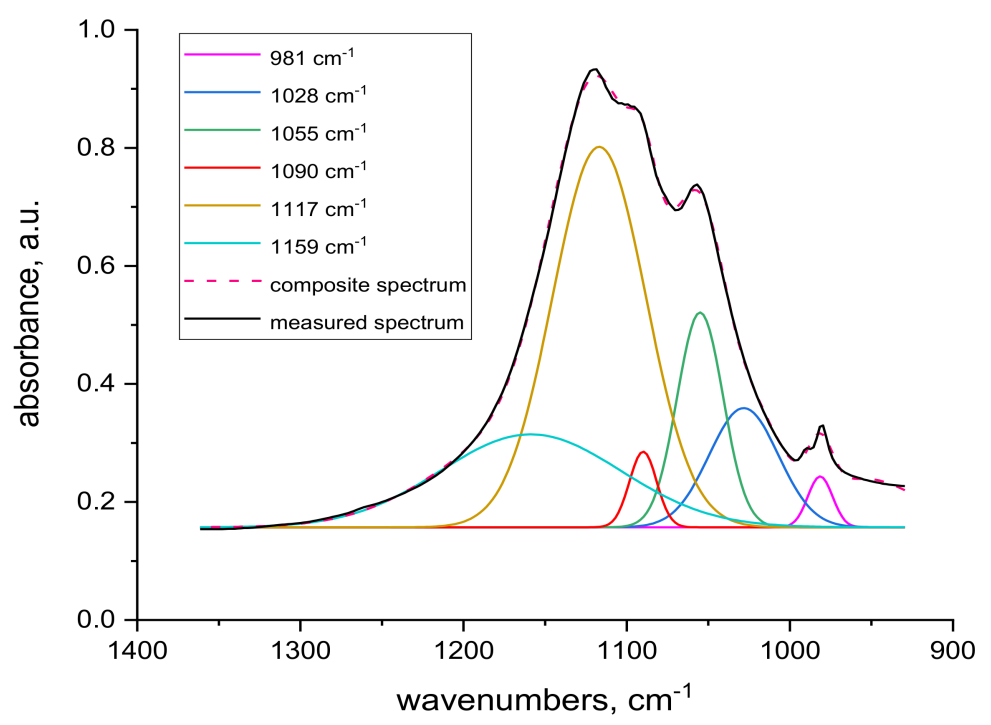

Figure 9. Deconvolution of transmission $\mathrm{KCr}\left(\mathrm{SO}_{4}\right)_{2}$ spectrum.

Merging into a wider band in samples of 21 and $153 \mathrm{kGy}$ (Figure $7 \mathrm{~b}, \mathrm{c}$ ) indicates a wider involvement of this anion in the interaction due to the structural changes after the irradiation. The band around $1120 \mathrm{~cm}^{-1}$ belonging to cystine dioxide [21] is indicated in the non-contacted sample in the volume of the non-irradiated sample and disappears with increasing dose (Figure $5 \mathrm{a}-\mathrm{c}$ ); it is hardly noticeable on the surface (Figure $5 \mathrm{~d}-\mathrm{f}$ ). This is because the absorbed energy of electron beam already causes the formation of cysteine acid as the final oxidation product at the expense of cystine dioxide. In the contacted samples, the situation is the same, although the absorption maximum of $\mathrm{KCr}\left(\mathrm{SO}_{4}\right)_{2} \cdot 12 \mathrm{H}_{2} \mathrm{O}$ in this region may distort the situation. A well readable band at $1170 \mathrm{~cm}^{-1}$ in the spectra of the non-contacted sample (Figure 5a-f) indicates cysteic acid [38,39] and cystine oxides both in volume and on the sample surface. Corresponding bands of the contacted samples are less pronounced in volume, at most in the $153 \mathrm{kGy}$ sample (Figure 7a-c), while only a tip-off on the band is visible on the surface (Figure $7 \mathrm{~d}-\mathrm{f}$ ). This demonstrates the consumption of these species as a result of their interaction with $\mathrm{Cr}(\mathrm{III})$, especially on the fiber surface. The bands at 1240 and $1260 \mathrm{~cm}^{-1}$ characterize the conformational forms of the secondary wool structure [21]. On the surface of the non-contacted wool (Figure $5 \mathrm{~d}-\mathrm{f}$ ) there are distinct bands at $1240 \mathrm{~cm}^{-1}$ belonging to Amide III (mixed $\mathrm{NH}$ vibrations) in $\beta$-sheet and disordered structure [21] and are observable as adjacent bands of $\alpha$-helical structure bands at 1260 $\mathrm{cm}^{-1}$ (Figure $5 \mathrm{a}-\mathrm{c}$ ). It can be observed that with respect to the volume of the non-contacted samples, the ratio of the bands at 1260 to $1240 \mathrm{~cm}^{-1}$ increases with increasing dose (Figure $5 \mathrm{a}-\mathrm{c}$ ), indicating the transformation of the $\beta$-sheet and disordered structure into an $\alpha$-structure. In the contacted wool volume, these $\alpha$-conformation bands $\left(1260 \mathrm{~cm}^{-1}\right)$ are almost unidentifiable (Figure $7 \mathrm{a}-\mathrm{c}$ ), and there is no sign of $\alpha$-helical structure on the surface (Figure 7d-f). Although in volume of the contacted wool, the presence of a rest of the $\alpha$-structure $\left(1260 \mathrm{~cm}^{-1}\right)$ is only indicated, it is apparent that the ratio of the bands at 1260 to $1240 \mathrm{~cm}^{-1}$ increases with dose (Figure $7 \mathrm{a}-\mathrm{c}$ ) even if the initial values are significantly different from the non-contacted sample. Thus, the morphology of this doublet varies with dose, and $\mathrm{Cr}$ contact, among other factors, affects the overall sorption result.

The 1450 and $1750 \mathrm{~cm}^{-1}$ bands belonging to the carboxyl -COOH [38] are identifiable in the volume and on the surface of both sample types. The reduction of the band in the contacted samples (Figure 8) compared to the starting samples (Figure 6) corresponds to the consumption of a portion of the carboxyl in reaction with $\mathrm{Cr}(\mathrm{III})$. Another band where changes can be identified is the band at $3300 \mathrm{~cm}^{-1}$ (Figures 6 and 8). It belongs to bonded -OH and bonded $-\mathrm{NH}$ or $-\mathrm{NH}_{2}$ groups [38]. It is observable as a wider band only on the surface of both sample types (Figures $6 \mathrm{~d}-\mathrm{f}$ and $8 \mathrm{~d}-\mathrm{f}$ ). When compared with alkyl bands around $2900 \mathrm{~cm}^{-1}$ (considered constant) in the non-contacted samples (Figure $6 \mathrm{~d}-\mathrm{f}$ ), for $0 \mathrm{kGy}$ sample the absorption ratio at $3300 \mathrm{~cm}^{-1}$ to alkyl bands is almost equal and with 
increasing dose this ratio slightly rises in favor of $3300 \mathrm{~cm}^{-1}$. In the contacted samples (Figure $8 \mathrm{~d}-\mathrm{f}$ ) this development is different; in the $0 \mathrm{kGy}$ sample, the $3300 \mathrm{~cm}^{-1}$ band is higher than the alkyl band, in $21 \mathrm{kGy}$, ratio of the $3300 \mathrm{~cm}^{-1}$ to the alkyl band becomes equal, and at $153 \mathrm{kGy}$, the alkyl band is higher than the $3300 \mathrm{~cm}^{-1}$ band. The different tendencies observed are attributed to the gradual involvement of $-\mathrm{OH},-\mathrm{NH}$ or $-\mathrm{NH}_{2}$ groups in interaction with $\mathrm{Cr}$ (III) to form complex (es). Small bands at $3075 \mathrm{~cm}^{-1}$, measured only on the surface of both non-contacted (Figure $6 \mathrm{~d}-\mathrm{f}$ ) and contacted (Figure $8 \mathrm{~d}-\mathrm{f}$ ) samples, may belong to free secondary amines or bonded -OH in carboxylic acid [38]. They correspond with the large band at $3450 \mathrm{~cm}^{-1}$ belonging to bonded $-\mathrm{OH}$ and free $-\mathrm{NH}$ or $-\mathrm{NH}_{2}$ groups [38] observed only in the volume of these samples (Figures $6 a-c$ and $8 a-c$ ). This indicates that the interaction of $\mathrm{Cr}$ (III) with the wool takes place mainly on the surface.

\section{Materials and Methods}

\subsection{Chemicals}

Chromium potassium sulphate dodecahydrate $\mathrm{KCr}\left(\mathrm{SO}_{4}\right)_{2} \cdot 12 \mathrm{H}_{2} \mathrm{O}$ p.a., supplied by Gavax, Ltd., (Vranov n/Topl'ou, Slovakia) was used as $\mathrm{Cr}$ (III)-sorbate. For sorption experiments, solutions of $\mathrm{Cr}$ (III) in deionized water at concentrations of (12.5-25-50-60-70) $\mathrm{mmol} \cdot \mathrm{dm}^{-3}$ were applied.

Natrium hydroxide $\mathrm{NaOH}$, hydrochloric acid $\mathrm{HCl}$ and potassium chloride $\mathrm{KCl}$, all analytical grade, were supplied by Slavus Ltd. (Bratislava, Slovakia) and used to adjust the $\mathrm{pH}$ of the solutions when necessary.

L-Arginine 98\% was supplied by company Alfa Aesar, Karlsruhe, Germany.

\subsection{Preparation of Adsorbent}

Sheep wool of Suffolk-Merino crossbreed bred in West Slovakia comes from spring cut. The wool was taken from the saddle part and the fiber thickness was in the range of 27-33 $\mu \mathrm{m}$. The wool was firstly scoured in tepid water and then thrice in an ultrasonic bath of $40^{\circ} \mathrm{C}$ during $10 \mathrm{~min}$, rinsed with deionized water, and freely dried for 3 days. Irradiation of the samples stored in cardboard boxes was performed in UELR-5-1S linear electron accelerator (FGUP NIIEFA, Petersburg, Russia) with installed energy of $5 \mathrm{MeV}$ and operated by Progresa Final SK company (Bratislava, Slovakia ). The samples with absorbed doses of (0-21-40-99-153-258-410) kGy were stored under common conditions and room temperature.

\subsection{Procedure of PZC and IEP Estimation}

The point of zero charge (PZC) indicates the $\mathrm{pH}$ value at which an adsorbent submerged in an electrolyte exhibits zero net electrical charge on the surface [40]. Below the PZC, the adsorbent surface is positively charged and attracts anions. Conversely, above PZC the surface is negatively charged and attracts cations/repels anions. Isoelectric point (IEP) is known as the $\mathrm{pH}$ at which both positive and negative charges on the different functional groups balance each other out [41]. While for simple amino acids IEP can be estimated by calculation from $\mathrm{pK}_{\mathrm{a}}$ data, for proteins, the IEP is understood to be the point at which the hydrogen ion concentration of a solution in which the ionization of the acid groups of the amphoteric substances, ampholytes, is equal to the ionization of the basic groups [30]. Here, the IEP estimation can be performed by measuring the change in $\mathrm{pH}$ of the wool extract in a neutral salt solution with set initial $\mathrm{pH}$ value following [28].

A set of samples with a one-year lapse from irradiation was selected for the experiment. The samples were contacted with $0.05 \mathrm{M} \mathrm{KCl}$ solutions whose $\mathrm{pH}$ was adjusted from 2 to 8 . After $24 \mathrm{~h}$ contact, the resulting $\mathrm{pH}$ of the potassium chloride bathes was measured to determine its change from the set value.

The value of $\mathrm{pH}$ was measured using Orion2 Star $\mathrm{pH}$-meter (Thermo Scientific, Waltham, MA, USA) equipped with Sen Tix 42 plastic electrode with temperature sensor. The accuracy of the 
equipment indicated by the manufacturer was $\pm 0.002 \mathrm{pH}$. Applying double measuring the relative error did not exceed $0.5 \%$.

\subsection{Spectral Measurements}

Visible spectrometry (Specord 50 Plus, Analytikjena, Germany) with a $1 \mathrm{~cm}$ cell was used to determine the $\mathrm{Cr}$ (III) residual content in the bath. The comparative sample was always the aqueous extract from the wool with dose corresponding to the measured sample, obtained after $24 \mathrm{~h}$ contact of the sample with deionized water under the same conditions.

Infrared spectrometry was applied to analyze the wool samples before and after contact with $\mathrm{Cr}$ (III). Fourier transform infrared spectroscopy-attenuated total reflectance (FTIR-ATR) measurements were performed with a NICOLET 8700TM FTIR ${ }^{\mathrm{TM}}$ spectrometer (Thermo Scientific, Waltham, MA, USA) using a single bounce ATR accessory equipped with a Ge crystal. For transmission measurements the fibers were immersed directly into liquid nitrogen for 5-10 $\mathrm{min}$ and then ground in the ball mill. The ground powder in an amount of $0.9-1.9 \mathrm{mg}$ was molded into $\mathrm{KBr}$ pellets. The corresponding spectra were taken throughout the whole middle infrared region $\left(400-4000 \mathrm{~cm}^{-1}\right)$ and normalized by converting to unit mass. In case of $\mathrm{KCr}\left(\mathrm{SO}_{4}\right)_{2} \cdot 12 \mathrm{H}_{2} \mathrm{O}$, the quantity was $1.7 \mathrm{mg}$. For each measurement, the spectral resolution was $4 \mathrm{~cm}^{-1}$ and 64 scans were performed. The acquired spectra were analyzed using the OMNIC ${ }^{\mathrm{TM}}$ v.8.1 spectroscopic software (Thermo Electron Scientific Instruments LLC, Madison, WI, USA).

\subsection{Batch Sorption Experiments}

The sorption experiments were conducted with $\mathrm{Cr}(\mathrm{III})$ solutions applying concentrations in the range of (12.5-70) $\mathrm{mmol} \cdot \mathrm{dm}^{-3}$. After being cut to $3-5 \mathrm{~mm}, 0.2 \mathrm{~g}$ of wool fibers was placed into a glass cup with a cap and the testing solution of $20 \mathrm{~cm}^{3}$ in volume was added. The content of the glass cup was first shaken for $6 \mathrm{~h}$ at room temperature on a laboratory horizontal shaker (Witeg SHR-2D, Labortechnik $\mathrm{GmbH}$, Wertheim, Germany) and then kept in static mode for next $18 \mathrm{~h}$. Then the remaining solution was filtered through KA5 filter paper and used for determination of residual $\mathrm{Cr}(\mathrm{III})$. Every sorption procedure was carried out in triplicate.

The parameter $\mathrm{q}$ as a measure of wool (bio)sorptivity was calculated using the following equation:

$$
\mathrm{q}=\left(\mathrm{x}_{1}-\mathrm{x}_{2}\right) / \mathrm{m}
$$

where $\mathrm{q}$ is the sorptivity defined as the amount of sorbate in mmol per $1 \mathrm{~g}$ of the sorbent for individual wool samples when particular testing solution is applied in specified concentration, $\mathrm{x}_{1}$ is the amount of the sorbate added in the initial solution $(\mathrm{mmol}), \mathrm{x}_{2}$ is residual amount of the sorbate in the solution after its contact with the wool sample ( $\mathrm{mmol}), \mathrm{m}$ is the mass of the wool sample taken for analysis $(\mathrm{g})$.

\section{Conclusions}

Sheep wool, both natural and electron beam irradiated with absorbed doses of (0-410) kGy, was subjected to PZC and IEP examination using $\mathrm{pH}$ change in $0.05 \mathrm{M} \mathrm{KCl}$ solutions with adjusted $\mathrm{pH}$ after the contact with the wool samples. The increasing dose shifted PZC to lower values with an overall $\mathrm{pH}$ drop in the range of $0.65 \mathrm{pH}$ units, while the IEP for the irradiated wool increased by $0.05 \mathrm{pH}$ units, equally for all dosed samples compared to $\mathrm{pH}$ of 3.35 for the non-irradiated wool. In the sorption experiments with $\mathrm{KCr}\left(\mathrm{SO}_{4}\right)_{2} \cdot 12 \mathrm{H}_{2} \mathrm{O}$, the influence of hydrolytic processes of the sorbate on the change of the VIS spectrum used for the evaluation of the $\mathrm{Cr}$ (III) sorption by the wool was taken into account. This was eliminated by using a $\mathrm{pH}$ adjusted aqueous wool extract corresponding to the resulting $\mathrm{pH}$ of the sorption bath and used as a solvent for the preparation of the calibration solutions. The calculated sorptivity for $\mathrm{Cr}(\mathrm{III})$ in the range of (12.5-70) $\mathrm{mM}$ concentration showed a monotonically rising trend without extremes despite the expected analogy with the sorption of $\mathrm{Cu}$ (II) or $\mathrm{Co}(\mathrm{II})$ showing extremes. Compared to the non-irradiated wool, lower doses (21-40 kGy) induced better sorption than those 
higher doses. The model reaction of $\mathrm{Cr}$ (III) with arginine resulted in an insoluble chelate, which was used to draft a concept of the octahedronic Cr-complex model. Infrared spectral data from the surface and volume of the wool fibers confirmed $\mathrm{Cr}$ (III) chemisorption involving the formation of complex chromite salts based on carboxylates and cysteinates. The morphology of bands of secondary structure ( $\alpha, \beta$, amorphous) changed with the position in the fiber (surface/volume) and dose, as well as due to the interaction with $\mathrm{Cr}(\mathrm{III})$. The amino- and hydroxyl-type ligands provided by various chains are precondition for cross-linking formation. The interaction of $\mathrm{Cr}(\mathrm{III})$ with the wool was indicated preferentially on the fiber surface.

Author Contributions: Conceptualization, M.P. and J.B.; methodology, J.B., M.P. and K.J.; formal analysis, J.B., A.K., R.M. and V.M.; investigation, J.B., M.P. and K.J.; writing—original draft preparation, M.P.; writing-review \& editing, M.P., J.B. and K.J.

Funding: This research received no external funding.

Acknowledgments: The authors thank Zuzana Branišová from Trnava University, Department of Fine Art Education, for the Graphical Abstract authorship.

Conflicts of Interest: The authors declare no conflict of interest.

\section{References}

1. Bedemo, A.; Chandravanshi, B.S.; Zewge, F. Removal of trivalent chromium from aqueous solution using aluminum oxide hydroxide. SpringerPlus 2016, 5, 1288. [CrossRef] [PubMed]

2. Park, M.; Park, J.; Kang, J.; Han, Y.-S.; Jeong, H.Y. Removal of hexavalent chromium using mackinawite (FeS)-coated sand. J. Hazard. Mater. 2018, 360, 17-23. [CrossRef] [PubMed]

3. Dong, K.; Liu, Q.; Wei, G.; Hu, T.; Yao, J.; Zhang, X.; Gao, T. Mussel-inspired magnetic adsorbent: Adsorption/reduction treatment for the toxic $\mathrm{Cr}(\mathrm{VI})$ from simulated wastewater. J. Appl. Polym. Sci. 2018, 135, 46530. [CrossRef]

4. Li, Q.; Liu, Y.; Yu, X.; Li, L.; Zhang, X.; Lu, Z.; Lin, J.; Yang, X.; Huang, Y. Removal of Cr(iii)/Cr(vi) from wastewater using defective porous boron nitride: A DFT study. Inorg. Chem. Front. 2018, 5, 1933-1940. [CrossRef]

5. Zhu, F.; He, S.; Liu, T. Effect of $\mathrm{pH}$, temperature and co-existing anions on the Removal of $\mathrm{Cr}(\mathrm{VI})$ in groundwater by green synthesized nZVI/Ni. Ecotox. Environ. Saf. 2018, 163, 544-550. [CrossRef]

6. Chand, R.; Watari, T.; Inoue, K.; Luitel, H.N.; Torikai, T.; Yada, M. Chemical modification of carbonized wheat and barley straw using $\mathrm{HNO}_{3}$ and the adsorption of $\mathrm{Cr}(\mathrm{III})$. J. Hazard. Mater. 2009, 167, 319-324. [CrossRef]

7. Lyubchik, S.I.; Lyubchik, A.I.; Galushko, O.L.; Tikhonova, L.P.; Vital, J.; Fonseca, I.M.; Lyubchik, S.B. Kinetics and thermodynamics of the $\mathrm{Cr}$ (III) adsorption on the activated carbon from co-mingled wastes. Colloid Surf. A 2004, 242, 151-158. [CrossRef]

8. Su, M.; Fang, Y.; Li, B.; Yin, W.; Gu, J.; Liang, H.; Li, P.; Wu, J. Enhanced hexavalent chromium removal by activated carbon modified with micro-sized goethite using a facile impregnation method. Sci. Total. Environ. 2019, 647, 47-56. [CrossRef]

9. Choi, K.; Lee, S.; Park, J.O.; Park, J.-A.; Cho, S.-H.; Lee, S.Y.; Lee, J.H.; Choi, J.-W. Chromium removal from aqueous solution by a PEI-silica nanocomposite. Sci. Rep. UK 2018, 8, 1438. [CrossRef]

10. Mortazavian, S.; An, H.; Chun, D.; Moon, J. Activated carbon impregnated by zero-valent iron nanoparticles (AC/nZVI) optimized for simultaneous adsorption and reduction of aqueous hexavalent chromium: Material characterizations and kinetic studies. Chem. Eng. J. 2018, 353, 781-795. [CrossRef]

11. Yang, Y.; Chen, N.; Feng, C.; Li, M.; Gao, Y. Chromium removal using a magnetic corncob biochar/polypyrrole composite by adsorption combined with reduction: Reaction pathway and contribution degree. Colloids Surf. A 2018, 556, 201-209. [CrossRef]

12. Tyagi, U.; Khandegar, V. Biosorption potential of Vetiveria zizanioides for the Removal of chromium(VI) from synthetic wastewater. J. Hazard. Toxic. Radioactive Waste 2018, 22, 04018014. [CrossRef]

13. Surendran, G.; Baral, S.S. Biosorption of $\mathrm{Cr}(\mathrm{VI})$ from wastewater using Sorghastrum Nutans, L. Nash. Chem. Ecol. 2018, 34, 762-785. [CrossRef] 
14. Vilardi, G.; Ochando-Pulido, J.M.; Verdone, N.; Stoller, M.; Di Palma, L. On the removal of hexavalent chromium by olive stones coated by iron-based nanoparticles: Equilibrium study and chromium recovery. J. Clean. Prod. 2018, 190, 200-210. [CrossRef]

15. Quiton, K.G.; Doma, B., Jr.; Futalan, C.M.; Wan, M.-W. Removal of chromium(VI) and zinc(II) from aqueous solution using kaolin-supported bacterial biofilms of Gram-negative E. coli and Gram-positive Staphylococcus epidermidis. Sustain. Environ. Res. 2018, 28, 206-213. [CrossRef]

16. Xiao, R.; Wang, J.J.; Li, R.; Park, J.; Meng, Y.; Zhou, B.; Pensky, S.; Zhang, Z. Enhanced sorption of hexavalent chromium $[\mathrm{Cr}(\mathrm{VI})]$ from aqueous solutions by diluted sulfuric acid-assisted $\mathrm{MgO}$-coated biochar composite. Chemosphere 2018, 208, 408-416. [CrossRef]

17. Samuel, M.S.; Shah, S.S.; Subramaniyan, V.; Qureshi, T.; Bhattacharya, J.; Pradeep Singh, N.D. Preparation of graphene oxide/chitosan/ferrite nanocomposite for Chromium(VI) removal from aqueous solution. Int. J. Biol. Macromol. 2018, 119, 540-547. [CrossRef]

18. Balkaya, N.; Bektas, N. Chromium(VI) sorption from dilute aqueous solutions using wool. Desalin. Water Treat. 2009, 3, 43-49. [CrossRef]

19. Balköse, D.; Baltacioğlu, H. Adsorption of heavy metal cations from aqueous solutions by wool fibers. J. Chem. Technol. Biot. 1992, 54, 393-397.

20. Ghosh, A.; Collie, S.R. Keratinous materials as novel absorbent systems for toxic pollutants. Defence Sci. J. 2014, 64, 209-221. [CrossRef]

21. Porubská, M.; Hanzlíková, Z.; Braniša, J.; Kleinová, A.; Hybler, P.; Fülöp, M.; Ondruška, J.; Jomová, K. The effect of electron beam on sheep wool. Polym. Degrad. Stabil. 2015, 111, 151-158. [CrossRef]

22. Hanzlíková, Z.; Lawson, M.K.; Hybler, P.; Fülöp, M.; Porubská, M. Time-Dependent Variations in Structure of Sheep Wool Irradiated by Electron Beam. Adv. Mater. Sci. Eng. 2017, 2017. [CrossRef]

23. Hanzlíková, Z.; Braniša, J.; Hybler, P.; Šprinclová, I.; Jomová, K.; Porubská, M. Sorption properties of sheep wool irradiated by accelerated electron beam. Chem. Pap. 2016, 70, 1299-1308. [CrossRef]

24. Hanzlíková, Z.; Braniša, J.; Jomová, K.; Fülöp, M.; Hybler, P.; Porubská, M. Electron beam irradiated sheep wool - Prospective sorbent for heavy metals in wastewater. Sep. Purif. Technol. 2018, 193, 345-350. [CrossRef]

25. Porubská, M.; Kleinová, A.; Hybler, P.; Braniša, J. Why Natural or Electron Irradiated Sheep Wool Show Anomalous Sorption of Higher Concentrations of Copper(II). Molecules 2018, 23, 3180. [CrossRef]

26. Braniša, J.; Jomová, K.; Kovalčíková, R.; Hybler, P.; Porubská, M. Role of Post-Exposure Time in Co(II) Sorption of Higher Concentrations on Electron Irradiated Sheep Wool. Molecules 2019, 24, 2639. [CrossRef]

27. Kosmulski, M. IEP as a parameter characterizing the $\mathrm{pH}$-dependent surface charging of materials other than metal oxides. Adv. Colloid. Interfac 2012, 171-172, 77-86. [CrossRef]

28. Nacke, H.; Gonçalves, A.C.; Coelho, G.F.; Schwantes, D.; Compagnolo, M.A.; Völz Leismann, E.A.; Conradi, J.É.; Miola, J.A. Removal of Cd (II) from water using the waste of jatropa fruit (Jatropha curcas L.). Appl. Water. Sci. 2017, 7, 3207-3222. [CrossRef]

29. Capablanca, J.S.; Watt, L.C. Factors Affecting the Zeta Potential at Wool Fiber Surfaces. Text. Res. J. 1986, 56, 49-55. [CrossRef]

30. Harris, M. The isoelectric point of wool. Bur. Stand. J. Res. 1932, 8, 779-785. [CrossRef]

31. Pušić, T.; Boban, A.; Dekanić, T.; Soljačić, I. The sorption ability of textile fibres. Vlakna a Textil 2011, 18, 7-15.

32. Hamada, Y.Z.; Makoni, N.; Hamada, H. Three Very Different UV-VIS Absorption Spectra of Three Different Transition Metals Found in Biological Solutions. Electron. J. Biol. 2016, 2, 6-9.

33. Porterfield, W.W. Inorganic Chemistry: A Unified Approach, 2nd ed.; Academic Press: London, UK, $1993 ;$ p. 921. ISBN 0-12-562981-8.

34. Drljaca, A.; Spiccia, L. Early stages of the hydrolysis of Chromium(III) in aqueous solution-X. Kinetics of formation of trimer from monomer and dimer. Polyhedron 1995, 14, 1653-1660. [CrossRef]

35. Hiroishi, D.; Matsuura, C.; Ishigure, K. Hydrolysis of chromium(III) ion and solubility of chromium(III) oxide in high temperature water. Mineral. Mag. 1998, 62, 626-627. [CrossRef]

36. Wang, B.; Yang, W.; McKittrick, J.; Meyer, M.A. Keratin: Structure, mechanical properties, occurrence in biological organisms, and efforts at bioinspiration. Prog. Mater. Sci. 2016, 76, 229-318. [CrossRef]

37. Šima, J.; Koman, M.; Kotočová, A.; Segl’a, P.; Tatarko, M.; Valigura, D. Anorganická Chémia, 2nd ed.; STU: Bratislava, Slovakia, 2011; pp. 375-378. ISBN 978-80-227-3579-7. (In Slovak)

38. Thermo Scientific. Infrared Correlation Chart. 2015. Available online: http://ftirsearch.com (accessed on 2 May 2016). 
39. Milata, V.; Segl'a, P.; Brezová, V.; GatiaL, A.; Kováčik, V.; Miglierini, M.; Stankovský, Š.; Šíma, J. Aplikovaná Molekulová Spektroskopia; STU: Bratislava, Slovakia, 2008; pp. 543-558. ISBN 978-80-227-2960-4.

40. Lyklema, J. Fundamentals of Interface and Colloid Science. In Solid-Liquid Interfaces, 1st ed.; Academic Press: San Diego, CA, USA, 1995; Volume 3, pp. 101-109. ISBN 0-12-460524-9.

41. Debajyoti, D. Biochemistry, 1st ed.; Academic Publishers (Elsevier): London, UK, 1978; 634p, ISBN 9788187504825.

Sample Availability: Samples of the compounds are not available from the authors.

(C) 2019 by the authors. Licensee MDPI, Basel, Switzerland. This article is an open access article distributed under the terms and conditions of the Creative Commons Attribution (CC BY) license (http://creativecommons.org/licenses/by/4.0/). 